\title{
A Escola Nacional de Saúde Pública: origens e história do ensino da saúde pública em Portugal
}

\author{
Luís Graça \\ Escola Nacional de Saúde Pública, Universidade NOVA de Lisboa, Lisbon, Portugal
}

\section{Palavras-Chave}

Saúde pública $\cdot$ Ensino $\cdot$ História $\cdot$ Portugal

\section{Resumo}

Desde a reforma sanitária de Ricardo Jorge (1899-1901), até à criação da Escola Nacional de Saúde Pública e Medicina Tropical, em 1 de janeiro de 1967, passaram-se mais de 6 décadas. Em 1903, começou a funcionar o Instituto Central de Higiene (ICH), de que o atual INSA - Instituto Nacional de Saúde Doutor Ricardo Jorge é o herdeiro direto, hoje sem funções de ensino. A atual Escola Nacional de Saúde Pública também remonta ao ICH mas é o resultado do ensaio de vários modelos institucionais e organizacionais: o modelo Rockeffeler, o modelo OMS, o modelo universitário. É este período (1903-1966) que vamos revisitar, dando conta da evolução do ensino da saúde pública em Portugal.

(c) 2019 The Author(s) Published by S. Karger AG, Basel on behalf of NOVA National School of Public Health

\section{The National School of Public Health: Origins and History of Public Health Education in Portugal}

\author{
Keywords \\ Public health · Education · History · Portugal
}

\section{Abstract}

Since the health reform of Ricardo Jorge (1899-1901), until the creation of the National School of Public Health and Tropical Medicine, on January 1, 1967, more than 6 decades passed. In 1903, the Central Institute of Hygiene (ICH) began operating, of which the current INSA - National Institute of Health Dr. Ricardo Jorge is the direct heir, today with no teaching functions. The current National School of Public Health also dates back to the ICH but is the result of the test of several institutional and organizational designs: the Rockefeller model, the WHO model, the university model. It is this period that we will revisit (1903-1966) giving an account of the evolution of the teaching of public health in Portugal.

(c) 2019 The Author(s) Published by S. Karger AG, Basel on behalf of NOVA National School of Public Health

\section{KARGER


Durante muito tempo fora da Universidade, o ensino e/ou a investigação em saúde pública faz-se hoje, fundamentalmente, na Escola Nacional de Saúde Pública, unidade orgânica da Universidade NOVA de Lisboa (ENSP/ NOVA), Instituto de Higiene e Medicina Tropical, unidade orgânica da mesma universidade (IHMT/NOVA), Instituto Nacional de Saúde Doutor Ricardo Jorge (INSA) e Instituto de Saúde Pública da Universidade do Porto (ISPUP). As três primeiras têm uma história em comum. O ISPUP, mais jovem, não pode deixar de se reconhecer na (e dar continuidade, renovada, à) herança transmitida pelo portuense Ricardo Jorge.

Com a reforma sanitária de 1899-1901, protagonizada por Ricardo Jorge (Porto, 1858-Lisboa, 1939) [1] chegam a Portugal os conceitos do moderno sanitarismo, em franco desenvolvimento em países como a Inglaterra e a Alemanha, pioneiros da revolução industrial e urbana. E começam justamente por influenciar a legislação, a política e a administração da saúde, a par do ensino e da investigação. Basta referir a criação, logo em 1899, do Instituto Central de Higiene (abreviadamente, ICH) e, ainda antes, do Real Instituto Bacteriológico, em 1892, sem esquecer a Escola de Medicina Tropical, em 1902, anexa ao Hospital Colonial [2].

A reforma da saúde pública de 1899-1901 não surgiu, porém, num contexto social e político favorável, dada a crise, económica e financeira, da última década do séc. XIX e da primeira do séc. XX, a par do esgotamento do modelo "fontista" de desenvolvimento e do modelo "rotativista" de governação, que vai marcar a II e última parte (1890-1910) do regime vigente, a Monarquia Constitucional.

E, no entanto, Portugal estava na moda, ou pelo menos Lisboa, a capital: em 1906, é um extraordinário sucesso, do ponto de vista científico e social, a realização do $X V$ Congrés International de Médecine (Lisbonne, 19-26 avril 1906) [3] que juntou a elite médica, nacional e internacional. A língua oficial era o francês [4]. E até o rei D. Carlos fez o discurso de boas vindas... em francês, a língua científica da época!

Ricardo Jorge, "professeur à l'École de médecine de Lisbonne, inspecteur général des services sanitaires," presidiu à XIV secção do Congresso, "Higiene e Epidemiologia.” Não há, porém, qualquer referência ao ainda recente e obscuro Instituto Central de Higiene, de que ele era diretor.

Por essa ocasião, foi inaugurado o novo edifício da Escola Médico-Cirúrgica de Lisboa [5] no Campo de Santana, onde se realizaram as reuniões científicas do Congresso. Estamos em plena "belle époque"! É também o fim de uma época. O rei seria assassinado dois anos depois, em 1908, tal como Miguel Bombarda, a verdadeira alma do Congresso, logo a seguir, na véspera do golpe de Estado de 5 de outubro de 1910 que levou à implantação da República.

A certidão de nascimento do ICH tem a data de 1899 (art. $19^{\circ}$ do decreto de 28 de dezembro [6], com a assinatura do governo "progressista" de Luciano Cordeiro); e o seu primeiro regulamento é de 24 de dezembro de 1901 (incluído no Regulamento Geral de Saúde e Beneficência Pública [7], art. $115^{\circ}$ e ss., que tem a chancela do governo "regenerador" de Hintze Ribeiro).

Entra em funcionamento no ano seguinte e, logo em 1903, realiza-se o primeiro curso de medicina sanitária (CMS). O ICH vai manter esta designação até 1945 , altura em que passou a chamar-se Instituto Superior de Higiene (ISH), na sequência da reforma sanitária de Trigo de Negreiros (reorganização dos serviços de assistência, pelo decreto- lei ${ }^{\circ} 35108$, de 12 de dezembro de 1945 [8]). A partir de 1971, pelo decreto-lei n ${ }^{\circ} 413 / 71$, de 27 de setembro [9], passa a ser, de pleno direito, o Instituto $\mathrm{Na}$ cional de Saúde (INSA). Ostenta, desde 1929, o nome do seu fundador e primeiro diretor, Ricardo Jorge.

Do ICH pode dizer-se que pertence à $1^{\text {a }}$ era da moderna saúde pública, anterior à nossa transição demográfica e epidemiológica (que podemos situar nos anos 30/40) e à fundação da Organização Mundial de Saúde (OMS) (1948), enquanto agência especializada das Nações Unidas.

A atual Escola Nacional de Saúde Pública (ENSP), por sua vez, é herdeira direta do $\mathrm{ICH}$, mas só vai surgir na $2^{\mathrm{a}}$ era da moderna saúde pública, na segunda metade do séc. XX, em 1967, com uma primeira tentativa, prematura, da sua criação, logo no início da década de 1960, por proposta legislativa do então ministro da saúde e assistência, Martins de Carvalho, e com apoio da OMS.

Todavia, já nos anos 30 tinha havido uma tentativa (frustrada) de criar, em Lisboa, a Escola Nacional de Higiene Pública (ENHP), com o apoio técnico e financeiro da Rockefeller Foundation. São dessa época, o Instituto de Malariologia (1939), o Centro de Saúde de Lisboa (1939) e a Escola Técnica de Enfermeiras (1940) onde pela primeira vez se ousa fazer a formação de pessoal de enfermagem de saúde pública, com um plano de estudos inovador de que faziam parte disciplinas como a sociologia e a psicologia. A criação destas três instituições só foi possível graças ao apoio da Fundação Rockefeller.

Em 1967, quando o Estado Novo e o Império Colonial Português se aproximavam do fim, a saúde pública e a medicina tropical fizeram um "casamento de conveniên- 
cia," efémero, dando origem à Escola Nacional de Saúde e Medicina Tropical (ENSPMT) (1967-1972). Foi uma solução "ad hoc," "topdown," imposta por decreto, e que rapidamente levou de novo à separação dos dois ramos, com a criação, em 1972, da ENSP e do Instituto de Higiene e Medicina Tropical (IHMT).

Mas a história (atribulada) do ensino da saúde pública em Portugal não acaba aqui... A Escola passa então a ser "secção de ensino" do INSA que, com atribuições alargadas e enriquecidas, no âmbito da reforma de saúde de Gonçalves Ferreira e Baltazar Rebelo de Sousa (Decreto-lei 413/71, de 27 de setembro) [9], veio em boa hora substituir o velhinho ISH, de há muito objeto de críticas pela inoperância, subfinanciamento, falta de instalações e escassez crónica de meios, sobretudo laboratoriais e de ensino, bem como pela degradação pedagógica e o desprestígio do curso de medicina sanitária / curso de saúde pública. E aqui continua a saga do ensino da saúde pública em Portugal... até que a ENSP se autonomiza em 1976, está em regime de instalação até 1981, e integra, em 1994, a Universidade NOVA de Lisboa, não sem passar por um período conturbado de ameaça de extinção e/ou de incerteza quanto ao seu futuro institucional, na vigência do XII Governo Constitucional. De facto, logo em finais de 1991, transita para a tutela do Ministério da Educação e, até ao despacho $\mathrm{n}^{\circ}$ 14/ME/94 [10], de 5 de abril de 1994, da Ministra da Educação, publicado em Diário da República, II Série, $n^{\circ} 99$, de 28 de abril de 1994, conhece dois anos de grande perturbação da sua organização e funcionamento.

São as seis décadas que antecedem a criação da Escola Nacional de Saúde Pública e Medicina Tropical que revisitamos neste artigo.

\section{Do Instituto Central de Higiene (1899) ao Instituto Superior de Higiene Doutor Ricardo Jorge (1945)}

De acordo com o $\mathrm{n}^{\circ} 1$ do art. $115^{\circ}$ do Regulamento Geral dos Serviços de Saúde e Beneficência Pública, de 24 de dezembro de 1901, o ICH tinha como missão, entre outras, a de "ministrar a instrução especial técnica e conferir o tirocínio profissional prático, necessário como habilitação de admissão aos lugares de médicos e engenheiros do corpo de saúde pública" [7].

No campo do ensino sanitarista, o ICH (e depois o ISH, até 1966) limitou-se à realização (anual, a partir de 1903) do curso de edicina anitária (CMS), de um curso de Engenharia Sanitária (aliás, apenas uma edição, em 1903), de vários cursos de Visitadoras Sanitárias (iniciados tardiamente, em 1931, e com maior regularidade entre 1946

Origens e história do ensino da saúde pública em Portugal e 1952), bem como de cursos de aperfeiçoamento para: (i) subdelegados de saúde (iniciados em 1939, passando a ter regularidade anual entre 1946 e 1965); e (ii) engenheiros sanitários (apenas entre 1954 e 1957).

Refira-se ainda a realização de outros cursos destinados a outros profissionais (agentes sanitários, e técnicos médios e superiores de laboratório) e, por fim, mais tardiamente, a criação do curso de Medicina do Trabalho (em 1963, e então como especialidade do curso de Medicina Sanitária, e depois autonomizado no ano seguinte, para logo ser transferido para a ENSPMT, em 1967).

Cronologicamente, o ICH terá sido "o $10^{\circ}$ a ser fundado no mundo, e seguindo os melhores modelos - o inglês e o alemão," como lembrou, em 1960, Fernando da Silva Correia [11], porventura o mais fervoroso, leal, reverencial e acrítico dos discípulos e admiradores de Ricardo Jorge. Até então o ensino da higiene (ou saúde pública), tanto em Portugal como no resto da Europa, era feito exclusivamente nas escolas médicas.

Diga-se, de passagem, que o pioneirismo de Portugal nesta como noutras matérias vai ser evocado até à exaustão para, no Estado Novo, não se fazer (ou ir adiando) as reformas que a modernização da saúde e da economia impunham; neste caso a inércia da reforma de Ricardo Jorge [12], idolatrado "ad nauseam" como o maior higienista português de todos os tempos, e um dos maiores da Europa do seu tempo, dava (ou deu) muito jeito à elite dirigente do regime.

Â matrícula do CMS eram "admitidos os médicos diplomados pelas três escolas do continente do reino." O mesmo sucedendo com o curso de Engenharia Sanitária, aberto aos engenheiros diplomados pelas respetivas escolas [13]. Uma vez diplomados, os médicos podiam concorrer aos lugares de médicos de saúde pública, e os engenheiros ficavam habilitados a concorrer aos lugares de engenheiro sanitário das delegações de saúde de Lisboa e Porto (de resto muito escassos: dois e um, respetivamente). Aliás, por portaria de 3 de março de 1904, o CMS passava a ser obrigatório para provimento de lugares do quadro de funcionários dos serviços sanitários e condição de preferência para a nomeação de facultativos municipais.

Esta disposição legal tornava o curso, em princípio, mais atrativo: um leque variado de médicos que se destacaram nas suas profissões e na vida pública (incluindo a política), tinham os cursos de medicina sanitária e/ou de medicina tropical. Mas a abertura aos "quintanistas," os alunos de medicina que tivessem concluído o último ano do curso médico-cirúrgico das Escolas Médico-Cirúrgicas de Lisboa ou Porto, e a realização de cursos no Porto e em Coimbra, acabaram por conduzir a práticas de faci- 
litismo, absentismo, indisciplina e até más práticas e fraudes académicas, comprometendo, logo à nascença, a qualidade e o prestígio do CMS.

Sobre este ponto, Fernando da Silva Correia escreve: "A competência dos professores e a correção da maior parte das lições era indiscutível. Mas o facto é que o Curso de Medicina Sanitária, tanto como em Coimbra como no Porto e em Lisboa, não se tornou só inútil, ultrapassou os limites do escândalo" [14].

Em 1903, por edital de 9 de janeiro, foi aberta a matrícula para o CMS (bem como o de Engenharia Sanitária), com a duração de quatro meses (de 14 de março a 12 de julho de 1903). Também por edital, de 21 de fevereiro de 1903, é aprovado, para os dois cursos, o programa das disciplinas, com o respetivo pessoal docente e os horários.

Sabe-se que, logo em 1903, se inscreveram 50 médicos e quatro engenheiros, dos quais fizeram exame mais de metade (31 médicos e dois engenheiros) (taxa de sucesso de 61\%). Até 1945, ano em que o CMS, ministrado em Lisboa, vai sofrer uma remodelação, tinham-se matriculado 2,873 médicos (dos quais apenas 94, ou sejam, 3.3\%, eram mulheres) e fizeram exame 1,426 (dos quais só 3.4\% eram do sexo feminino). O que equivale a uma taxa de sucesso de apenas $50.1 \%$.

Pode-se considerar o programa do CMS inovador, e até bastante compreensivo, para a época, no nosso país, incluindo, no entanto, conhecimentos que hoje consideraríamos básicos ou elementares mas que não faziam parte das matérias ministradas, por exemplo, no curso de medicina de Coimbra, no final do séc. XIX, com exceção da "medicina legal, higiene pública e polícia higiénica" (que já era, em 1872, a $12^{\mathrm{a}}$ cadeira, do $5^{\circ}$ ano, dada pelo prof. Fernando Augusto de Andrade Pimentel e Mello) [15]. De resto, nas escolas médico-cirúrgicas de Lisboa e Porto como na faculdade de medicina de Coimbra, a higiene era uma matéria perfeitamente secundária no currículo do curso, sendo muito tributária do dispositivo jurídico-normativo e penal. E só se vai autonomizar da medicina legal em 1900 [16].

Recorde-se que em 1899, são criadas as morgues, sendo a de Lisboa, organizada por [José Joaquim da] Silva Amado. Em 1906, no XV Congresso Internacional de Medicina, em Lisboa, as duas áreas já estão completamente separadas: a Higiene e Epidemiologia (secção XIV), e a Medicina Legal (secção XVI).

Conhece-se as disciplinas e as matérias dos cursos de 1903 e 1904 (e os respetivos docentes) [17]: 1. Direito sanitário; 2. Demografia e estatística sanitária; 3.1. Meteorologia e clima; 3.2. Hidrografia; 3.3. Solo. Orografia. Telurologia; 4.1. Química sanitária; 4.2. Bromatologia; 5.
Veterinária; 6.1. Epidemiologia geral; 6.2. Profilaxia contra a tuberculose, a febre tifoide, a varíola, o sezonismo, a raiva, etc.; 6.3. Moléstias zimóticas; 7. Desinfeção e desinfetantes; 8.1. Higiene da infância; 8.2. Higiene escolar; 8.3. Higiene industrial; 9a. Prática sanitária oficial; 9b. Prostituição. Profilaxia da sífilis; 10 . Sanidade marítima; 11.1. Higiene das classes pobres; 11.2. Polícia mortuária; 12. Abastecimento de águas; 13. Higiene habitacional.

Em 1904, o CMS (já não se realizou o de engenharia sanitária) tinha uma carga de 400 horas: 17 semanas, de $2^{\mathrm{a}}$ feira a sábado, quatro horas por dia, das $11 \mathrm{~h}$ às $16 \mathrm{~h}$, no período compreendido entre 14 de março e 16 de julho. Havia três aulas teóricas, das $11 \mathrm{~h}$ às $16 \mathrm{~h}$, com intervalos de meia hora; e trabalhos de laboratório, da parte da tarde, de $4^{\mathrm{a}}$ feira a sábado.

A disciplina com maior peso, com 3 horas semanais, era a ${ }^{\circ} 9$ a (Prática sanitária oficial). A parte da tarde, das $14 \mathrm{~h}$ às $16 \mathrm{~h}$, estava reservada a trabalhos laboratoriais no âmbito da disciplina $n^{\circ} 4$ (Química sanitária e Bromatologia) e da disciplina $n^{\circ} 6.1$ (Epidemiologia geral). Estas duas eram então as cadeiras principais, ocupando em aulas teóricas e teórico-práticas metade da carga horária total do curso [18].

Quanto ao corpo docente, ele era recrutado entre os melhores (ou, pelo menos, mais reputados) membros do escol académico e profissional da época: médicos, médicos veterinários, engenheiros sanitários, químicos, inspetores, professores, oriundos da Escola Médico-Cirúrgica de Lisboa, do Real Instituto de Bacteriologia Câmara Pestana, da Inspeção Geral dos Serviços Sanitários do Reino e dos serviços de saúde pública... Mas, curiosamente, de 1904 a 1930 não constam os seus nomes na folha oficial [19].

Um dos calcanhares de Aquiles do ICH era não ter, de facto, um quadro próprio de pessoal docente, tendo por isso que recorrer a preletores externos... Era, necessariamente, um corpo docente instável, com uma preparação científica e pedagógica muito desigual, remunerado em função do número de aulas, seguramente voluntarioso e competente nas suas áreas. Ninguém se atreve, porém, a criticar a displicente gestão académica de Ricardo Jorge, que esteve à frente do ICH durante duas décadas e meia (1902-1926), como se tratasse de um cargo vitalício, ao mesmo tempo que acumulava outras funções importantes, dentro e fora do país: professor de higiene na escola médico-cirúrgica (e depois faculdade de medicina) de Lisboa, e inspetor geral da saúde (desde 1899), diretor geral de saúde com a I República (desde 1912), representante do país no Office Internacional d'Hygiène Publique e também no comité de higiene da Sociedade das Nações, 
mesmo depois de jubilado e até à data da sua morte, em 1939.

A Higiene industrial ( $\left.n^{\circ} 8.3\right)$ era então uma das matérias pioneiras, a par da Higiene da infância $\left(n^{\circ} 8.1\right)$ e da Higiene escolar ( $\mathrm{n}^{\circ} 8.2$ ), estando a cargo do professor Sabino Maria Teixeira Coelho: esta matéria compreendia "o trabalho e a saúde dos operários; o trabalho das mulheres e menores; a insalubridade industrial; estabelecimentos insalubres, incómodos e perigosos." Destaque também para a disciplina $n^{\circ} 13$, Higiene habitacional, matéria que, em 1903, era dada pelo engenheiro sanitário Bernardino António Barros Gomes. Por decreto de 14 de fevereiro de 1903 [20], tinha acabado de ser aprovado o regulamento, com 60 artigos, de "salubridade das edificações urbanas: condições higiénicas a adotar na construção dos prédios."

Por sua vez, esteve a cargo do professor Miguel Bombarda, entre 1903 e 1907, a disciplina n 11.1 (Higiene das classes pobres; alimentação e habitações; a mutualidade, a assistência pública e a higiene; hospitais e higiene hospitalar; asilos, sanatórios, balneários; polícia mortuária e cemitérios)... Em 1904, há uma reformulação do conteúdo programático, passando a ser: A assistência das classes pobres; higiene da infância, proteção sanitária das crianças; hospitais e higiene hospitalar; higiene escolar.

O CMS, criado em 1903, mudou de designação (pelo art. $16^{\circ}$ do decreto com força de lei, de 26 de maio de 1911 [21]). Com a República, passa a chamar-se Curso Especial de Higiene Pública, mas só arranca em 1914; com a Ditadura Militar, em 1926, e depois com o Estado Novo, voltou à primitiva designação, CMS, tendo vigorado até 1966, naturalmente com alterações curriculares e pedagógicas ditadas pelo tempo, a mais importante terá sido a de 1945, ano em que o ICH passa a designar-se por Instituto Superior de Higiene... [O seu quadro de pessoal continua a ser reduzido, não ultrapassando as três dezenas de funcionários (sede em Lisboa e delegações no Porto e em Coimbra, esta última nunca tendo chegado a abrir), em todo o caso, o dobro do quadro de pessoal inicial previsto em 1901].

Com a criação da Escola Nacional de Saúde Pública e Medicina Tropical, o CMS em 1967 passará a designar-se por Curso de Saúde Pública [e, em 1995, CESP (Curso de Especialização em Saúde Pública), na sequência da integração da ENSP na Universidade NOVA de Lisboa (em 1994)], fazendo parte, de há muito, do Programa de Formação do Internato Médico de Saúde Pública.

Dos cursos especiais de Higiene Pública, que se realizaram entre 1914 e 1926, não temos os planos de estudos nem conhecemos os nomes dos preletores ou docentes. Entretanto, e na sequência do decreto com força de lei, de

Origens e história do ensino da saúde pública em Portugal
22 de fevereiro de 1911 [22], que reformou o ensino médico, o ICH é anexado pedagogicamente à Faculdade de Medicina de Lisboa (art. $\mathrm{n}^{\circ} 1$ do decreto de 6 de abril do mesmo ano [23]). Logo a seguir, em 26 de maio, são reconstituídos e ampliados os serviços do Instituto. E em 16 de março do ano seguinte, é aprovado o regulamento do ICH, composto por um total de 43 artigos.

O ICH, por força do disposto no regulamento de 1912, deve também ficar, fisicamente, próximo da nova Faculdade de Medicina. Logo nesse ano, as suas instalações são transferidas de Santa Apolónia para o Campo de Santana. No essencial a sua missão não muda, mas vê as suas competências alargadas, enriquecidas e melhor especificadas do que no regulamento de 1901. Incumbe-lhe, em primeiro lugar, "ministrar o ensino da Higiene na Faculdade" ( $\mathrm{n}^{\circ} 1$ do art. $1^{\circ}$ do Regulamento). E só em $4^{\circ}$ lugar é que vem a organização de "cursos especiais e de aperfeiçoamento (...) para habilitação especial dos indivíduos que se destinem a funcionários de saúde", cursos esses também abertos a alunos ou diplomados de "qualquer Faculdade ou Escola" com interesse no "ramo da Higiene professada" (art. $21^{\circ}$ ), ou seja, continuam abertos a engenheiros, veterinários, farmacêuticos e outros, para além dos médicos.

Tem, pela primeira vez, um quadro de pessoal docente, embora muito reduzido (art. $4^{\circ}$ ), sendo composto pelo diretor (que é o professor de Higiene da Faculdade), 2 primeiros assistentes e 2 segundos assistentes. (Previa-se ainda o recurso a "assistentes livres" e "ajudantes," a nomear pelo diretor, conforme as necessidades de ensino.) Com o pessoal de secretaria $(n=11)$ e o pessoal de laboratório (serviço de química sanitária e serviço de vacina e bacteriologia sanitária) ( $n=16)$, o quadro de pessoal somava 32 lugares, mais do dobro do quadro original.

Passam-se também a publicar, a partir de 1912, e até 1938, os Arquivos do Instituto Central de Higiene. Apesar da escassez de recursos financeiros, a biblioteca do ICH contava já, em 1915, mais de milhar e meio de publicações não periódicas (em português, francês, inglês, alemão, espanhol e italiano) [24].

Trinta anos depois, é feita uma remodelação do CMS, a qual deve muito ao seu diretor, Carlos de Arruda Furtado [25]. Os seus principais pontos constam do respetivo regulamento, aprovado pelo Decreto ${ }^{\circ} 36050$, de 18 de dezembro de 1946 [26]. Em síntese: (i) os cursos funcionam "sob a superintendência" da direção-geral de Saúde; (ii) na sede do ISH, em Lisboa, no Campo de Santana, e nas suas delegações de Coimbra e Porto (quando instaladas...); (iii) as candidaturas são feitas por inscrição; (iv) abertura aos médicos, e já não aos finalistas de medicina, 
mas também aos médicos veterinários, aos engenheiros e aos arquitetos; (v) número limitado de vagas, fixadas pelo ministro do Interior; (vi) são condições de preferência na admissão à matrícula a maior classificação no curso universitário e o maior tempo de serviço prestado (em hospitais, centros de saúde e dispensários, "de preferência em meio rural"); (vii) as disciplinas são basicamente as mesmas, mas o ensino vai ter que se adaptar aos conhecimentos técnicos dos alunos; (viii) duração de 6 a 8 meses, fora o estágio; (ix) maior estabilidade do corpo docente; (x) aprovação anual superior do plano e programa do CMS bem como da distribuição dos professores das diversas disciplinas; (xi) reforço da componente teórico-prática; (xii) obrigatoriedade da frequência das aulas e dos estágios e assistência aos trabalhos práticos e às visitas de estudo; (xiii) perda de frequência com um número de faltas superior a $20 \%$ em qualquer disciplina; (xiv) elaboração de uma monografia final (sobre o estado sanitário de um concelho ou sobre um problema de saúde relevante, à escolha do aluno); (xv) exames finais, com provas escritas, orais e práticas; (xvi) não admissão à prova oral dos alunos que, na escrita, tenham obtido menos de 10 valores; (xvii) a nota final do curso resulta da média das médias das provas escrita, oral e prática, e tem a seguinte equivalência, numa escala de 0 a 20 valores: reprovado (menos de 10); suficiente (de 10 a 13); bom (de 14 a 15); bom, com distinção (de 16 a 17); muito bom, com distinção (de 18 a 20).

Os exames finais do CMS eram feitos perante um júri, presidido pelo diretor-geral de Saúde (ou seu representante), o diretor do curso e um vogal nomeado de entre os professores. Estes, por sua vez, eram nomeados pelo ministro da tutela, o do Interior, de "entre os funcionários dos serviços de saúde" ou de entre indivíduos, estranhos a esses serviços, mas que tenham "reconhecida competência para o ensino da respetiva disciplina" (art. $8^{\circ}$ do decreto 36050, de 18 de dezembro de 1946) [26]. A "gratificação" (sic) do diretor do CMS, professores e secretariado era fixada por despacho do ministro do Interior, depois de ouvido o indispensável (e sempre poderoso) ministro das Finanças.

Em 1947 eram catorze as cadeiras ou disciplinas do CMS (Vd. Tabela 1).

O programa incluía ainda estágios na Delegação de Saúde, Centro de Saúde, dispensários, postos de desinfeção, biblioteca, etc. (para além das aulas teóricas e práticas, demonstrações e visitas de estudo).

A maior carga letiva ia para a Epidemiologia e Técnica de Prolixia (I e II), da responsabilidade de Carvalho Dias e de Arnaldo Sampaio, respetivamente, com um total de
48 tempos (18 lições teóricas, 10 demonstrações e 20 visitas) (cerca de $22 \%$ do total).

Na cadeira de Higiene social e assistência médico-social (que era dada por Fernando da Silva Correia, diretor do ISH), eram já introduzidos "elementos de sociologia" (sic), tais como os determinantes sociais da saúde/doença, o papel da medicina social e do serviço social e ainda a metodologia do inquérito social e sanitário. A carga era de 12 lições teóricas, num total de 133 (9\%), com mais 6 visitas (cerca de 10\%) num total de 59. A higiene do trabalho, os acidentes e as doenças profissionais representavam $15 \%$ do total de lições teóricas, a que acresciam mais 10 visitas (c. de 17\%) do total.

Há aqui um "núcleo duro" de docentes que se mantém, entre 1947 e 1951 (Tabela 2), uns do Instituto (Fernando da Silva Correia, Bernardino de Pinho, Maria Ernestina da Graça Silva Mendes, Arnaldo Sampaio), outros dos serviços de saúde pública (António Augusto Carvalho Dias, Aníbal do Couto Nogueira e Heitor Vasco Mendes da Fonseca). E entram novos nomes: na Engenharia sanitária, o eng ${ }^{\circ}$ Renato Paletti Berger (em vez do eng ${ }^{\circ}$ Agnelo Prazeres); para a Higiene da alimentação, entra o dr. Guilherme Jorge Janz (1913-1999); Francisco Cambournac dá a cadeira de Sezonismo (matéria que em 1946/47 era abordada, por alto, na cadeira de Higiene rural); o prof António Meliço Silvestre (1900-1973), da Universidade de Coimbra, vem substituir, na cadeira de Demografia e estatística sanitária, o prof João [Avelar] Maia de Loureiro, entretanto falecido prematuramente aos 48 anos (1901-1949). Destaque para a primeira mulher docente, Maria Ernestina da Graça Silva Mendes, que dava as aulas práticas de Águas de abastecimento e higiene da alimentação.

No ano letivo de 1950/51, a carga letiva aumenta substancialmente: 190 lições teóricas, 84 lições teórico-práticas, mas diminuem, para 21, as visitas. (Tabela 2).

A avaliar pelo formato da monografia final, que era exigida aos participantes, bem como pelas visitas de estudo (incluindo escolas, refeitórios, cantinas...), o CMS era (ou continuava a ser) ainda muito orientado, nessa época, para o exercício das funções de "autoridade de saúde" ou "polícia sanitária."

Os docentes, por sua vez, eram recrutados entre os técnicos superiores dos serviços, quer da saúde quer da assistência: era o caso, por exemplo, do regente da cadeira de Higiene do trabalho, Aníbal do Couto Nogueira, antigo subdelegado de saúde de Lisboa, adjunto e depois inspetor chefe de Higiene do Trabalho e das Indústrias, inspetor superior de Saúde e Higiene em 1946, vogal do Conselho Superior de Higiene, autor de algumas pequenas 
Table 1. Instituto Superior de Higiene Dr. Ricardo Jorge: plano curricular do Curso de Medicina Sanitária (ano letivo de 1947)

\begin{tabular}{|c|c|c|c|c|}
\hline Cadeira ou disciplina & Regente / colaboradores & $\begin{array}{l}\text { No lições } \\
\text { teóricas }\end{array}$ & $\begin{array}{l}\text { No lições } \\
\text { práticas }\end{array}$ & $\begin{array}{l}\text { No } \\
\text { visitas }\end{array}$ \\
\hline Administração Sanitária & Carlos Arruda Furtado & 12 & $6(*)$ & \\
\hline Salubridade & Carlos Arruda Furtado / Jorge Niny / Sousa Fialho & 12 & & 6 \\
\hline Esgotos e Águas Residuais & Souto Teixeira & 10 & & 2 \\
\hline $\begin{array}{l}\text { Águas de Abastecimento e Higiene da Ali- } \\
\text { mentação (ii) }\end{array}$ & Maria Ernestina da Graça Silva Mendes & & $10(*)$ & \\
\hline Higiene Rural & $\begin{array}{l}\text { Fausto Landeiro (substituído por Carlos Arruda Furta- } \\
\text { do, Arnaldo Sampaio e engo Agnelo Prazeres) }\end{array}$ & 12 & & 6 \\
\hline Higiene do Trabalho & Aníbal do Couto Nogueira & 12 & & 6 \\
\hline Acidentes e Doenças Profissionais & Heitor [Vasco Mendes] da Fonseca & 8 & & 4 \\
\hline Higiene e Assistência Social & Fernando [Silva] Correia & 12 & & 6 \\
\hline Demografia e Estatística Sanitária & João Maia [Loureiro] (prof) & 7 & $3(*)$ & \\
\hline Total & & 133 & 29 & 59 \\
\hline
\end{tabular}

(*) Demonstrações. Fonte: Instituto Superior de Higiene Dr. Ricardo Jorge [27].

publicações neste domínio. A matéria relacionada com Acidentes e doenças profissionais" era dada, por sua vez, por Heitor [Vasco Mendes] da Fonseca. Quanto à Engenharia sanitária, em 1947, era assegurada pelo eng ${ }^{\circ}$ Agnelo Prazeres. Em 1950/51, aparece outro nome: eng ${ }^{\circ}$ Renato Paletti Berger (1903-1987).

O quadro do ISH era reduzido e continuava a ter muito pouco pessoal docente, recorrendo-se por norma à figura do docente convidado. Não admira, por isso, que em 1951, o diretor Fernando da Silva Correia lamente publicamente perder a valiosa colaboração do médico Guilherme Jorge Janz (1913-1999) (ligado ao laboratório de bromatologia e à pesquisa sobre vitaminas, especialista na área da patologia clínica), convidado para exercer funções no Instituto de Medicina Tropical, e que levou uma analista [28]. Nesse mesmo ano, Arnaldo Sampaio, chefe do serviço do Laboratório de Bacteriologia Sanitária ganhava uma bolsa de estudo, da Organização Mundial de Saúde, para durante um ano, em Londres, no National Insti- tute for Medical Research, se treinar nas técnicas de investigação sobre a gripe [28] (p. 58).

Para além do CSM, o ISH realizava também ações de formações mais curtas, como o curso de aperfeiçoamento para subdelegados de saúde, já atrás referido. Em 1951, por exemplo, de 15 de maio a 14 de junho, realizou-se o VII Curso. Teve a presença de 21 participantes, oriundos de norte a sul do país. Fica-se a saber que, com esta $7^{\mathrm{a}}$ edição, um total de 145 subdelegados de saúde (mais 5 guardas-mores ou estagiários) já tinham, desde 1939, participado nestes cursos de aperfeiçoamento que, com a II Guerra Mundial, foram interrompidos, sendo logo retomados em 1946.

O referido VII Curso consistiu em 25 lições sobre doenças contagiosas, 17 sobre assuntos vários, 22 sessões de estudo, 17 visitas de estudo e duas conferências, envolvendo um total de quatro dezenas de "preletores" (sic)... Fazendo um meticuloso balanço do curso, em jeito de prestação de contas à tutela (que era a direção-geral de 
Table 2. Instituto Superior de Higiene Dr. Ricardo Jorge: plano curricular do Curso de Medicina Sanitária e pessoal docente (ano letivo de 1950/51)

\begin{tabular}{|c|c|c|c|c|}
\hline Cadeira ou disciplina & Docente ou preletor & $\begin{array}{l}\text { No lições } \\
\text { teóricas }\end{array}$ & $\begin{array}{l}\text { No lições } \\
\text { práticas }\end{array}$ & $\begin{array}{l}\mathrm{N}^{\circ} \text { visi- } \\
\text { tas }\end{array}$ \\
\hline Administração Sanitária & Fernando da Silva Correia & 12 & 8 & \\
\hline Higiene Geral & Heitor Vasco Mendes da Fonseca & 20 & & 3 \\
\hline $\begin{array}{l}\text { Higiene da Alimentação e Águas de Abaste- } \\
\text { cimento }\end{array}$ & $\begin{array}{l}\text { Bernardino Vicente Álvaro de Pinho / Guilherme Jorge } \\
\text { Janz }\end{array}$ & 22 & & 3 \\
\hline Epidemiologia e Técnica da Profilaxia & António Augusto Carvalho Dias & 22 & & 4 \\
\hline Bromatologia & Maria Ernestina Graça Mendes & 12 & 6 & \\
\hline Bacteriologia Sanitária & António Arnaldo de Carvalho Sampaio & 15 & 60 & \\
\hline Doenças Profissionais & Heitor Vasco Mendes da Fonseca & 8 & & \\
\hline Organização e Assistência Social & Agostinho Joaquim Pires & 15 & 6 & \\
\hline Demografia e Estatística Sanitária & Meliço Silvestre / Maria Ernestina Graça Mendes & 15 & & 1 \\
\hline Total & & 190 & 84 & 21 \\
\hline
\end{tabular}

Fonte: Silva-Correia [51].

Saúde), o diretor do ISH, Fernando da Silva Correia [28] dá-nos uma informação preciosa sobre a origem (institucional) dos preletores das 42 lições: (i) 28 das lições (dois terços) foram proferidas por funcionários dos serviços da direção-geral de Saúde (sendo 6 dos serviços técnicos e 6 do próprio Instituto); (ii) do restante pessoal, 5 eram funcionários dos serviços da direção geral de Assistência; 7 eram docentes universitários (6 professores ou assistentes da Faculdade de Medicina, e um professor da Escola Superior de Medicina Veterinária); um era inspetor da Saúde Escolar, e um outro inspetor dos Serviços Pecuários (p. 63-72).

Constata-se, portanto, a baixa proporção de "pessoal da casa," com funções docentes: menos de 15\%. E há apenas duas mulheres, que eram técnicas superiores de laboratório do Instituto, e não propriamente do "quadro do pessoal docente": Adriana C. Figueiredo ("Bacteriologia das salmonelas") e Helena d'Ávila ("Bacteriologia das aguas de abastecimento")... Há ainda a registar dois nomes de preletores que virão a ser mais tarde docentes da ENSPMT (1967-72) e da ENSP (a partir de 1972): Cayolla da Mota ("Epidemiologia das bruceloses") e Arnaldo Sampaio ("Problemas no tratamento da sífilis").

Registe-se, por fim, a presença de três professores universitários: João Cândido da Silva Oliveira (1906-1991), "Aspetos do problema da raiva"; José Manuel Toscano de Vasconcelos Rico (1901-1988), "Aspetos terapêuticos das parasitoses intestinais"; e Eugénio Antunes Tropa (1910-1986), "Patologia veterinária e saúde pública." Em geral estes professores também estavam ligados ao Instituto Bacteriológico Câmara Pestana. E, no caso de Eugénio Tropa, à Faculdade de Medicina Veterinária do Instituto Superior Técnico.

Fazendo, em 1952, o balanço de meio século de história do Instituto [29], Fernando da Silva Correia coloca-se, tal como o seu mestre, na posição de vítima. No seu tempo, ainda era fácil usar o Instituto como arma de arremesso político contra a defunta I República e ao mesmo lisonjear os homens que detinham o poder, no Estado Novo. Para ele, o ICH tinha sido enredado, tal como Penélope, nas teias da ignorância, imprevidência, inveja, vaidade, ambição e maldade, seguramente alguns dos piores defei- 
tos da sociedade portuguesa da época. E refere a data, certamente funesta, de 1911, em que, com a criação da Faculdade Medicina, o Instituto é atraído para a sua órbita, sendo obrigado inclusive a transferir-se para o Campo de Santana (lei de 26 de maio de 1911).

Em 1901, Ricardo Jorge criara um Instituto, independente, pertencendo ao Ministério do Reino, sob tutela da Inspeção Geral dos Serviços Sanitários onde ele "pontificava" (sic). A reforma do ensino médico de 1911 vem "anexar" o Instituto à Faculdade de Medicina. O curso de Medicina Sanitária passou a chamar-se curso especial rde Higiene Pública, mas a qualidade científica e pedagógica não melhorou, continuando a ser frequentado por quintanistas de medicina. Aos laboratórios do Instituto, por seu turno, foram negadas as verbas de que precisava para se expandir e modernizar. Em suma, tanto a nível do ensino como da produção laboratorial, o balanço dos 14 anos de "regime universitário" foi dececionante, segundo Fernando da Silva Correia.

As coisas não melhoraram, todavia, com a Ditadura Militar (1926-1933) nem na $1^{\text {a }}$ fase do Estado Novo, até à reforma sanitária de Trigo de Negreiros, em 1945. Fernando da Silva Correia não tem dúvidas: "De 1902 a 1939, o Instituto viveu quase exclusivamente devido ao prestígio científico e intelectual do seu diretor" [28] (p. 176). E continua: "Não fosse a guerra [a II Guerra Mundial] e certamente teria ido por diante o plano encetado de levar a cabo (a Câmara de Lisboa chegou a conceder terreno para esse fim) a construção dum edifício novo e de instalações modernas, com o auxílio da Fundação Rockefeller, à qual se deve a criação ou a remodelação da maior parte dos melhores Institutos de Higiene do Mundo" [29] (p. 177). E aqui há uma referência, justíssima, ao papel do sucessor de Ricardo Jorge, o José Alberto de Faria, no cargo de diretor-geral de saúde.

É um período da história da saúde pública ainda mal conhecido.

\section{O projeto de Escola Nacional de Higiene Pública, segundo o modelo da Fundação Rockefeller (1937)}

De facto, de há muito que era reclamada a construção de um edifício próprio, adequado às funções do $\mathrm{ICH}$, e ao mesmo tempo a criação da Escola Nacional de Higiene Pública (ENHP), seguindo o figurino dos "institutos de higiene" da Fundação Rockefeller.

Foi o próprio Marcelo Caetano, procurador e relator do parecer da Câmara Corporativa sobre o Estatuto da Assistência Social [30], quem veio lembrar, em 1943, que,

Origens e história do ensino da saúde pública em Portugal tendo sido Portugal pioneiro na criação do ICH ("um instituto de investigação, ensino e propaganda da higiene pública") e do curso de medicina sanitária (CMS), precisava então de "acertar o passo" com o que de melhor se fazia lá fora nesta matéria.

Escrevia o relator (e futuro sucessor de Salazar), não sem ironia: "Aproveitou-se já então a prática de muitos países (Ricardo Jorge, precursor português, apresentou um relatório sobre o ensino da higiene... na Holanda) e outros aproveitaram depois as conclusões das conferências."

Por outro lado, relembrava que, anos antes, em 1936, ainda em vida de Ricardo Jorge, o dr. José Alberto de Faria, diretor-geral da Saúde ["que tem clamado sem cessar (e geralmente sem sucesso) pela resolução dos problemas nacionais da saúde pública" (sic)], havia visitado, "a convite da Fundação Rockefeller," os institutos de higiene da Polónia, Áustria, Hungria e Jugoslávia, tendo elaborado, no seu regresso, um relatório da visita, publicado sob o título de "Preceitos sanitários" [31].

Nesse relatório, José Alberto Faria fazia referência à sua proposta ao Governo da "construção do edifício do Instituto de Higiene e a criação da Escola Nacional de Higiene Pública (sic)," citava a portaria de 8 de novembro de 1934, que constituiu "uma comissão encarregada de elaborar o programa e o anteprojeto das instalações de uma instituição de higiene"; e mencionava "a disposição - manifestada em hora de lúcida visão no decreto $\mathrm{n}^{\circ}$ 22386, de 1 de Abril de 1933 - em que se estava de aceitar largamente a colaboração técnica e financeira já solicitada à Fundação Rockefeller."

E concluía Marcelo Caetano [32]: "Por isso a Câmara Corporativa se limita a reconhecer a absoluta necessidade de uma séria preparação especializada, num ambiente técnico e moralmente estimulante e formativo, dos médicos destinados às tarefas sanitárias da assistência social, fazendo votos por que, também neste capítulo, se entre no caminho das realizações, como preliminar de qualquer reforma de envergadura" (p. 123).

Pelo supracitado decreto 22386, de 1 de abril de 1933, Portugal passava, a partir desse ano, a figurar na lista dos países, aliados dos EUA, beneficiários da ajuda técnica e financeira da Fundação Rockefeller, através da sua International Health Division (1927-1951). O diretor geral de Saúde, José Alberto Faria, muito lutou, de facto, a partir de 1931, para obter o apoio, a Portugal, desta influente organização norte-americana a quem se ficará a dever a criação, entre nós, de três instituições de referência, já citadas: o Instituto de Malariologia (1939), o Centro de Saúde de Lisboa (1939) e a Escola Técnica de Enfermeiras (1940). 
Apesar de membro relativamente influente da União Nacional, com acesso direto a Salazar, José Alberto Faria não terá tido, no entanto, o peso político suficiente para concretizar outras medidas propostas pela Fundação Rockefeller, entre as quais a modernização do ICH e a criação da ENHP, à semelhança da Escuela Nacional de Sanidad, do país vizinho, criado em 1924, em Madrid. Foi, de resto, a partir do exemplo de cooperação com Espanha, que o diretor-geral de Saúde, sucessor de Ricardo Jorge, procurou explorar as vantagens de uma eventual ajuda técnica e financeira, no domínio do desenvolvimento sanitário, por parte da milionária Fundação Rockefeller.

Em carta de 1932, George Strode, representante da Fundação na Europa, lembrava a José Alberto Faria os critérios mínimos por que se deveria reger "um moderno serviço de higiene pública," baseado nos princípios da gestão, e que Portugal teria que adotar e assegurar: (i) serviços técnicos dirigidos e desempenhados por pessoal devidamente especializado; (ii) emprego a tempo inteiro ("full-time"); (iii) vencimento compatível para atrair os melhores (médicos e enfermeiras visitadoras sanitárias); (iv) cobertura da população inteira (adultos e crianças).

Em abril de 1932, George Strode vem a Portugal, na companhia de outro médico, Rolla Hill, da International Health Division (que, na Europa, tinha a sua sede em Paris), para fazer o diagnóstico da situação sanitária do país. A avaliação que foi feita era preocupante (alta taxa de mortalidade infantil, elevada morbimortalidade devida a doenças transmissíveis como a tuberculose, o paludismo, as doenças entéricas, etc.), e as recomendações foram bastante exaustivas e exigentes... A falta de pessoal especializado (médicos e engenheiros sanitários, enfermeiras de saúde pública, etc.) era gritante e o ICH não tinha capacidade de resposta, começando pelas instalações e pelo pessoal docente e de apoio...

É nesse ano que é feito o convite a José Alberto Faria para visitar centros de saúde, rurais e urbanos, e institutos de higiene, em quatro países da europa central e de leste: Áustria, Polónia, Hungria e Jugoslávia. Essa viagem de estudo só se viria a concretizar quatro anos depois (entre 25 de maio e 19 de junho de 1936).

O diretor-geral de Saúde far-se-ia então acompanhar por um dos seus braços direitos, Carlos Arruda Furtado, bem como pelos citados representantes da Fundação, George Strode e Rolla Hill. É na sequência dessa viagem que José Alberto de Faria escreve o seu relatório, destinado antes de mais ao ministro da tutela, o do Interior, Mário Pais de Sousa (1891-1949), conterrâneo e homem da confiança de Salazar.
Procurando tirar ensinamentos práticos dessa missão, e em particular da visita aos institutos ou escolas de higiene pública, criados com apoio da Fundação (Budapeste, 1925; Varsóvia, 1926; Zagrebe, 1927), bem como outras instituições de saúde, tais como Einsenstadt (1929), na Áustria, ou o centro de saúde do bairro Mokotow, de Varsóvia, José Alberto de Faria faz (ou retoma) uma série de propostas, algumas das quais já integravam uma publicação sua, anterior ("Administração Sanitária," Lisboa, 1934): (i) o ensino sanitário deve fazer-se através da Escola Nacional de Higiene Pública (ENHP), sendo esta uma secção de ensino (sic) do Instituto Central de Higiene Dr. Ricardo Jorge (ICH); (ii) acoplado à ENHP, deve existir um ou mais centros de saúde (ou "centros de demonstração sanitária”); (iii) a população-alvo da ENHP são os médicos sanitários, os engenheiros sanitários, as visitadoras sanitárias, as enfermeiras-visitadoras; (iv) a tutela do ICH e da ENHP deverá continuar a ser a Direção Geral de Saúde; e, por fim, (v) à medida das disponibilidades financeiras do país, deverá ser criada uma rede de centros de saúde, locais, concelhios, junto das misericórdias e casas do povo, em que a figura principal seja a enfermeira visitadora sanitária.

O autor relembra o teor da portaria de 8 de novembro de 1934, pela qual fora constituída uma "comissão," composta por um engenheiro (Francisco Melo Ferreira de Aguiar) e um arquiteto (Carlos João Chambers Ramos), além do diretor-geral de Saúde, encarregada da elaboração do programa e do anteprojeto das "instalações de uma instituição de higiene, solicitadas pela Direção-Geral de Saúde ao Ministério das Obras Públicas e Comunicações."

Ano e meio depois, José Alberto de Faria apontava como dificuldade maior a "de se marcar o terreno a ceder para as instalações [, o que] tem até agora protelado qualquer prática resolução a tomar pela comissão nomeada" [30] (p. 89).

Parece que o Governo (ou a Câmara Municipal de Lisboa) chegou a disponibilizar um terreno, no Campo de Santana, com vista à construção do ICH e da ENHP... No entanto, a conjuntura política e económica nacional e internacional (crise dos anos 30, saneamento das finanças públicas, consolidação do regime do Estado Novo, guerra civil de Espanha, etc.) não terá ajudado à concretização do projeto [33].

Em 2013, Ferreira [33], que analisou a correspondência entre o diretor geral de Saúde e os representes da International Health Divison, da Fundação Rockefeller, trocada nos anos 30 (e arquivada no fundo histórico da biblioteca da Direção-Geral de Saúde), diz que, na se- 
quência das exigências que a Fundação fizera em 1932, José Alberto Faria apresentou, em abril de 1937, o projeto da ENHP, uma escola com sede em Lisboa, que deveria juntar o ensino da saúde pública e da medicina tropical, a par da enfermagem de saúde pública, através da fusão do ICH, dependente do Ministério do Interior, com o IMT (Instituto de Medicina Tropical), que era tutelado pelo Ministério das Colónias, e que havia sido criado dois anos, em 1935, sucedendo à Escola de Medicina Tropical, de 1902 (que, por falta de instalações próprias, continuaria a funcionar, até 1958, no rés-de-chão do edifício da Cordoaria Nacional, que pertencia à Marinha). Parece que o modelo era então o da London School of Hygiene and Tropical Medicine (criada em 1924).

Posteriormente, em março de 1938, o diretor geral de Saúde fez, à Fundação, a proposta de criação do futuro Centro de Saúde de Lisboa (CSL), anexo à futura ENHP, seguindo o modelo do centro de saúde implantado em Varsóvia, no bairro Mokotov (que ele havia visitado em 1936, e então dirigido pelo dr. S. Stypulkovski). O CSL deveria ser um centro de saúde modelo, para o resto do país, e onde trabalhassem maioritariamente enfermeiras de saúde pública, além de local de estágio de estudantes das diferentes profissões de saúde, seguindo, portanto, o modelo institucional e organizacional da Fundação, a quem se pedia o respetivo financiamento e o necessário apoio técnico.

Em agosto de 1938, a Fundação ainda tentou reanimar o projeto da ENHP, proporcionando ao inspetor adjunto António Carvalho Dias uma visita, demorada, de 2 meses, a centros de saúde da Polónia, Hungria, Jugoslávia, Grécia e França. Contrariamente ao CSL, criado em 1939, o projeto da ENHP nunca se iria concretizar, por falta de vontade política e de empenho do Governo que não se esforçou minimamente por cumprir os compromissos assumidos com a Fundação, não tendo aproveitado inclusive, como devia, os respetivos bolseiros: pelo menos até agosto de 1938, tinham sido concedidas pela Fundação bolsas de estudo a "três delegados de saúde, dois engenheiros sanitários, uma enfermeira de saúde pública e um professor agregado da cadeira de Higiene da Faculdade de Medicina de Lisboa" (neste caso o João Maia de Loureiro (1901-1949), bolseiro em Paris, em 1932, tendo depois feito o doutoramento em Higiene e Saúde, na Universidade John Hopkins em 1938).

Com a eclosão da II Grande Guerra, a Fundação acabou por fechar os seus escritórios em Portugal (e no resto da Europa), e Lisboa deixou de poder ter, naquela altura, a sua ENHP, com a marca Rockefeller.

Origens e história do ensino da saúde pública em Portugal
Não é de mais lembrar que esta Fundação teve, entre as duas guerras mundiais, um papel de líder na conceção, planeamento, financiamento e construção das modernas escolas de saúde pública, nos EUA e em países seus aliados.

No pós-guerra, no início dos anos 50, o "novo edifício" do Instituto Superior de Higiene doutor Ricardo Jorge volta à baila... "E agora?," perguntava Fernando da Silva Correia, em 1952, ao celebrar os 50 anos do Instituto. "Deve encetar-se o trabalho de Penélope? Seria isso honroso para o Estado Novo? Será possível ressuscitar o espírito derrotista que o fez estagnar de 1905 a 1911 e de novo de 1911 a 1945? Entendemos que não. Será de admitir a hipótese de voltar para a Faculdade, tanto mais que no plano das edificações incluídas no novo Hospital Escolar, se conta com todos os laboratórios e serviços, sem exclusão da Anatomia, mas não se conta com a Higiene, a cujo Instituto se reservara um terreno independente, que o prof. Francisco Gentil não tinha dúvida em ceder ao Ministério do Interior para nele se instalar, autónomo da Faculdade, o Instituto Ricardo Jorge? A Câmara Municipal tem guardado, para esse fim, terreno próximo, em condições excelentes" [29].

O então diretor do Instituto Superior de Higiene tem reservas, fundadas na experiência passada, em relação a um eventual regresso do Instituto à Faculdade de Medicina, como acontecera no período da I República:

"A experiência de 1902 a 1945 exigiria então garantias sérias, a bem do País e da Saúde Pública, que, ao contrário do que julgam os não iniciados, não assenta apenas na clínica (aliás tão importante) nem nos laboratórios que a servem" (p. 189). E vem, não sem as necessárias cautelas, chamar a atenção para a Medicina Social, "essencialmente preventiva e educativa, que tantos teimam em confundir com Medicina Socializada ou com Medicina Coletiva (apenas clínica) - nessa Medicina Social que é afinal a única que está verdadeiramente e sempre ao alcance dos pobres e onde teriam colocação muitos dos diplomados pelas Faculdades, talentosos, competentes, mas pobres, eles também" [29, 34].

O diretor do Instituto fazia-se aqui eco das conclusões e recomendações do prof. António Silvestre Meliço [35], regente da cadeira de Higiene e Epidemiologia do curso médico-cirúrgico da Faculdade de Medicina da Universidade de Coimbra, representante português na importante conferência "médico-pedagógica," promovida pela OMS, em França, de 8 a 13 de dezembro de 1952 e que teve a participação de 19 estados-membros europeus. O tema foi justamente o ensino da Higiene, Medicina Preventiva e Medicina Social nas Faculdades de Medicina. 


\section{O projeto de Escola Nacional de Saúde Pública, do ministro da saúde e assistência Martins de Carvalho, segundo o modelo da OMS (1960)}

Em 26 de janeiro de 1961, na véspera do início da guerra colonial que iria marcar profundamente a sociedade portuguesa dos anos 60/70, e ditar inexoravelmente o fim do Estado Novo, dá entrada na Câmara Corporativa, para apreciação, o projeto de proposta de lei ${ }^{\circ}$ 517/VII, visando a criação da "Escola Nacional de Saúde Pública" (sic).

O projeto de diploma [36] é assinado pelo Ministro de Saúde e Assistência, Henrique de Miranda Vasconcelos Martins de Carvalho (1919-1994), com data de 26/12/ 1960. O que poucos sabiam, até há pouco tempo, é que Coriolano Ferreira, o primeiro diretor da Escola Nacional de Saúde Pública (1976-1981), é um dos 4 nomes que integra a comissão técnico-jurídica que redige o diploma, a par do dr. Bernardino Pinho (Direção-Geral de Saúde), do prof. Cândido de Oliveira (Faculdade de Medicina de Lisboa) e do prof. Paulo Antunes (consultor da OMS). O próprio projeto de diploma estava no limbo do esquecimento.

Esta iniciativa do X Governo (1933-1968), liderado por Salazar, no decurso da VII Legislatura (1957-1961), tem de ser entendida no contexto da criação, "por decreto," do Ministério da Saúde e Assistência, em 1958. De facto, só dez anos depois da fundação da OMS é que a saúde portuguesa, até então sob a tutela do Ministério do Interior, passa a ter um ministério próprio.

Na prática, tratou-se da simples elevação de um obscuro subsecretariado à categoria de ministério, através de um único artigo ( $\operatorname{art}^{\circ} 1^{\circ}$ do D.L. $\mathrm{n}^{\circ} 41825$, de 13 de agosto de 1958), que não define nem missão nem competências legais: "É criado o Ministério da Saúde e Assistência, para a qual são transferidos os serviços de saúde pública e os serviços de assistência pública, até ao presente dependentes do Ministério do Interior, e extinto o cargo de Subsecretário de Estado da Assistência Social." A este respeito, o próprio Henrique Martins de Carvalho dirá mais tarde o seguinte, em depoimento escrito em 1989, cinco anos antes de morrer: "O prof. Oliveira Salazar transigira com a opinião pública e criara o Ministério da Saúde; mas, no fundo, não tinha grande interesse em que este equacionasse (e procurasse atuar com alguma energia em) os problemas essenciais do setor. Desejava ter como ministro quem fosse um funcionário administrativo razoável e criasse boas relações, especialmente com os médicos, na altura bastante agitados e, para o tempo, invulgarmente reivindicativos" [37].
No preâmbulo da proposta de lei que visa criar a Escola Nacional de Saúde Pública (abreviadamente, ENSP), começa-se por fazer uma referência ao nosso pioneirismo em matéria de ensino da saúde pública, sendo Portugal "um dos primeiros países que instituíram o ensino sanitário" ao criar o ICH, em 1899, e ao incluir nele um curso de medicina sanitária (CMS).

Segue-se, no ponto 2, uma referência à "evolução," menos feliz, do CMS em que podiam distinguir-se "três períodos": (i) o primeiro (1903-1910) corresponderia à "fase embrionária da organização feita por Ricardo Jorge" e em que, por razões diversas, não se atingiu o nível esperado e desejado de qualidade; (ii) o segundo, de 1911 a 1945, caracterizou-se por um nível de ensino "bastante rudimentar," sendo o CMS "considerado um simples complemento formal do curso de medicina," e como tal técnica, científica e socialmente menos valorizado...

Mas foi justamente, no período de entre as duas guerras - lê-se no preâmbulo - que no estrangeiro surgiram as modernas escolas de saúde pública, com destaque para as de Harvard (1913), Londres (1924) e Zagrebe (1927), "graças à Fundação Rockefeller" bem como às "recomendações do Comité de Higiene da Sociedade das Nações." Haveria já, em 1939, cerca de 4 dezenas de escolas ou institutos, espalhados pelo mundo, que vieram responder a novas necessidades de formação do pessoal de saúde e à emergência de novos problemas de saúde...

Enfim, haveria um terceiro período, no pós-guerra, com a publicação do Estatuto da Assistência Social e do Decreto $\mathrm{n}^{\circ} 36$ 050, de 18 de dezembro de 1946 [26], em que o ensino da medicina sanitária [, com a restruturação científico-pedagógica de Carlos de Arruda Furtado em 1946], é melhorado, pelo menos em parte ( $\mathrm{n}^{\circ} 2$ do preâmbulo do projeto de proposta de lei $\mathrm{n}^{\circ} 519 / \mathrm{VII}$ ).

Justificada a sua criação, acrescenta-se, desde logo, que a ENSP seria uma escola "de nível universitário ou equiparado," dotada de "autonomia técnica e administrativa," com colaboração estreita com o Instituto Superior de Higiene Dr. Ricardo Jorge (sobretudo na parte laboratorial) e que deveria ter um corpo docente em "full-time" (sic) (ponto 3 do preâmbulo).

A colaboração entre as duas instituições (a Escola e o Instituto) ficaria simplificada, ao ser cometida a direção de ambas a um só diretor, que seria o diretor do Instituto. Tendo a Escola autonomia administrativa e técnica, a sua direção e administração são "entregues a um diretor e aos conselhos escolar e administrativo." O modelo de organização e funcionamento é o universitário: a novidade é "a representação dos assistentes e dos alunos no conselho escolar" (ponto 8). E, mais do que uma novidade, era uma 
“ousadia," vistas as coisas hoje, à distância de quase 6 décadas!

Para além das funções de ensino e formação, são atribuídas, à Escola a criar, funções de informação e disseminação do conhecimento (ponto 4), devendo para isso integrar um centro de saúde piloto. Por outro lado, a organização do seu ensino baseia-se no "sistema da divisão dos cursos por cadeiras," cada uma das quais com o seu professor titular ou regente (ponto 5).

E no ponto 6 do preâmbulo, diz-se que, "dada a sua finalidade de fomentar a competência técnica e o aperfeiçoamento progressivo do pessoal dos serviços de saúde e assistência, os cursos ordinários, agrupam-se em três categorias distintas" de formação: (a) pós-universitária; (b) profissional complementar; e (c) profissional de base. E depois na base IX especifica-se que os cursos ordinários de carácter pós-universitário se destinam a: (i) médicos de saúde pública; (ii) administradores hospitalares; (iii) engenheiros sanitários; e (iv) veterinários e farmacêuticos de saúde pública.

É garantida "a categoria técnica dos seus professores," adotando-se, para isso, "como princípio regulador do recrutamento, o concurso de provas públicas," organizado em moldes universitários (ponto 7). No $9^{\circ}$ e último ponto do preâmbulo, faz-se referências às disposições transitórias (Base XXVII: composição da comissão que há de fazer a nomeação do primeiro grupo de professores).

Entendia o legislador que, no início da década de 1960, se havia, entretanto, atingido "o clima próprio para a criação de uma escola nacional de saúde pública" (sic). Para a sua organização e funcionamento, nos primeiros tempos, contava-se, de resto, com o prometido auxílio da OMS, conforme fora acordado com esta, na $13^{\text {a }}$ Assembleia Geral, realizada em Genebra, de 3 a 20 de maio de 1960, e nomeadamente em matéria de contratação de professores estrangeiros (ponto 7).

O chefe da delegação portuguesa era justamente o ministro da tutela, Martins de Carvalho. E na ocasião um dos membros da delegação, o dr. G. Jorge Janz, aproveitou para intervir e congratular-se com o trabalho feito no ano anterior (1959) pelo diretor regional da OMS - África, e acrescentar que "Portugal was making great efforts to develop the health services in its African territories, and had been greatly helped in providing the necessary personnel by WHO fellowships and training courses" [38].

Pairava já no ar o fantasma da guerra colonial e da descolonização. Ora, em 1960, o diretor regional da OMS África ainda era o português Francisco Cambournac (que tomara posse do cargo em 1954, e que gozava da simpatia

Origens e história do ensino da saúde pública em Portugal dos novos países africanos, recém-independentes). Falando em nome da delegação portuguesa, a propósito das carreiras e da formação dos profissionais de saúde pública, G. Jorge Janz, numa das sessões de maio de 1960, fez referência explícita ao projeto de criação da ENSP e ao desenvolvimento dos serviços de saúde pública: "a draft statute had just been submitted to the National Assembly providing for the establishment of two separate career services in medicine and public health" (...); "that statute, together with the new National School of Public Health (sic), would be a decisive step towards the improvement and expansion of the health services" [38] (p. 226).

Portanto, haveria também um compromisso internacional, relativamente à criação da ENSP, e, ao que parece, promessa de apoio técnico da OMS. Mais: em maio de 1960, o governo (através do ministério da Saúde e Assistência) já estava a trabalhar no projeto de diploma legal da criação da nova escola. Ora, é preciso relembrar aqui alguns factos relevantes sobre o contexto político, interno e externo, em que surge este projeto de diploma: tendo Salazar sobrevivido politicamente à II Guerra Mundial e às falsas esperança da oposição democrática, o Estado Novo vai tentar entrar numa fase de reequilíbrio através da integração de Portugal no mundo dual da Guerra Fria (1949-1961). Eis algumas datas-chave: (i) 1948, adesão à OMS; (ii) 1949, adesão à NATO; (iii) 1955, integração (tardia) na ONU; (iv) maio-junho de 1958, campanha eleitoral do general Humberto Delgado para a presidência da República que fez tremer o regime; (v) 1959: adesão à EFTA - European Free Trade Association ; (vi) 1960: adesão ao Fundo Monetário Internacional (FMI) e ao Banco Internacional de Reconstrução e Desenvolvimento (BIRD); (vii) 1961: início da guerra colonial; e, facto não menos relevante, em (viii) 1962, é feito o pedido de abertura de negociações com a CEE - Comunidade Económica Europeia.

Embora Portugal fosse membro fundador da OMS, em 1948, tal como tinha sido, em 1919, da OIT (Organização Internacional do Trabalho), era um país com baixo nível de proteção social, e os indicadores de saúde (nomeadamente os de morbimortalidade) eram "terceiro-mundistas" (mesmo aos olhos de alguns apoiantes do regime, como Marcelo Caetano). Na campanha eleitoral do general Humberto Delgado, que teve forte adesão popular, o estado de atraso económico, social e cultural do país ganhou outra visibilidade, interna e externamente. Uma nova elite tecnocrática, mais jovem, de sensibilidade social e formação católica, consegue chegar ao poder, ou pelo menos à administração do Estado. Por outro lado, desde agosto de 1958, que os médicos e a respetiva ordem 
se agitam à volta da questão das carreiras médicas. (Em 1961, a Ordem dos Médicos divulga o relatório final sobre das carreiras médicas, de que foi relator João Miller Guerra).

Em resumo, e voltando ao projeto de diploma, sublinha-se o facto de a Escola dever estar devidamente articulada (e cooperar estreitamente) com o Instituto Superior de Higiene Doutor Ricardo Jorge. [Não é feita qualquer referência explícita ao Instituto de Medicina Tropical (IMT), que já existia entre nós desde 1935, herdeiro da Escola de Medicina Tropical, de 1902, nem a "modelos híbridos" como o da London School of Hygiene \& Tropical Medicine].

Quanto à organização do seu ensino, a ENSP basear-se-ia no "sistema da divisão dos cursos por cadeiras," a saber: (a) Bioestatística; (b) Microbiologia e Parasitologia; (c) Epidemiologia; (d) Salubridade; (e) Alimentação e Nutrição; (f) Higiene Materno-Infantil; (g) Higiene e Medicina do Trabalho; (h) Administração de Saúde Pública; (i) Administração Hospitalar; e (j) Sociologia.

Por fim, e ainda no preâmbulo do projeto de proposta de lei $n^{\circ} 519 / V I I$, o legislador faz questão de valorizar "a experiência já adquirida no ensino de determinadas matérias e na formação de sanitaristas," querendo significar com isso um aval de garantia de continuidade, garantia essa devida (i) às "qualidades" de quem dirigiu o ISH, (ii) ao empenho seus docentes e ainda (iii) "à herança espiritual que a todos legou o seu patrono [Ricardo Jorge], sem dúvida um dos maiores sanitaristas europeus da sua geração."

Como não podia deixar de ser, vinda de quem vinha, a proposta passou na Câmara Corporativa, com votos favoráveis dos procuradores (apenas dois votaram "vencidos," por quererem a nova Escola sob a tutela do ministério da Educação). Mas é importante chamar a atenção para a figura do relator, Jorge Horta, de seu nome completo, Jorge Augusto da Silva Horta (1907-1989), professor catedrático de anatomia patológica e diretor da Faculdade de Medicina, diplomado com os cursos de medicina sanitária e de medicina tropical e, na altura, bastonário da Ordem dos Médicos (1956-1962). Esteve em 3 legislaturas na Câmara Corporativa (a VI, a VII e a VIII, de 1953 a 1965). Subscreveu 7 pareceres, em dois dos quais foi relator: Instituto Nacional do Sangue (VI Legislatura, 1953/57) e Escola Nacional de Saúde (VIII Legislatura, 1961/65).

O relatório sobre a ENSP [39] é um notável documento, extenso, de 25 páginas e 90 referências bibliográficas (em português, francês e inglês), bem estruturado e bem escrito, com a marca académica do seu autor que, muito embora sendo um especialista da anatomia patológico, era tido também por ser um excelente professor, e por bem conhecer os problemas da saúde da população, da saúde pública, da investigação da saúde, da história da saúde e da medicina, da administração dos serviços de saúde, do exercício da profissão médica, da formação, desenvolvimento e carreiras dos profissionais de saúde, etc.

Atente-se no detalhado sumário do parecer, dividido em duas partes (I - Apreciação na generalidade; e II Exame na especialidade) e por capítulos. Refira-se, sumariamente, os pontos abordados na I parte: cap. I - Características fundamentais da medicina moderna e da saúde pública (dos $n^{\circ}$ s 5 a 15); cap. II - O ensino (pré e pós-graduado) da saúde pública (dos nº 16 a 30); cap. III - O projeto de proposta de lei (dos $\mathrm{n}^{\circ} 31$ a 41$)$.

$\mathrm{O}$ relator estava bem informado em relação às mais recentes orientações da OMS, naquela época, sobre o ensino da saúde pública, incluindo o conceito de escola de saúde pública [40]. Aí vão alguns excertos do preâmbulo (ponto 25): (...) "O relatório da Organização Mundial de Saúde sobre a organização do ensino pós-universitário da saúde pública (1961) define como escola de saúde pública uma instituição dotada de recursos apropriados que, independentemente das pesquisas que leva a efeito e dos serviços que fornece à coletividade no domínio da saúde pública, organiza para os membros do corpo médico e das profissões auxiliares um programa de estudos em "full-time," ocupando pelo menos um ano universitário ou tendo uma duração equivalente, e visando sobre as matérias indispensáveis à compreensão dos diversos problemas de saúde pública, assim como sobre os conceitos, a organização e os métodos que dirigem a sua solução."

Quanto às disciplinas ou cadeiras, a sua importância podia variar consoante as regiões e os países, como se sublinha no parecer da Câmara Corporativa: "Ao passo que em países fortemente industrializados o ensino da higiene industrial deve ter um lugar de destaque, noutros o ensino da epidemiologia e da profilaxia das doenças transmissíveis tem de ocupar o primeiro plano. Há, no entanto, um certo número de matérias que são comuns aos vários países."

Em todo o caso, o comité de peritos da OMS apontava um núcleo central (e universal) de matérias curriculares, objeto de ensino, investigação e ação comunitária, a saber: (i) administração da saúde pública: princípios e prática (incluindo noções fundamentais de gestão, direito, economia e sociologia); (ii) estatística aplicada à saúde; (iii) epidemiologia; (iv) saúde ambiental (incluindo a saúde ocupacional); e (v) microbiologia (incluindo parasitologia). 
Mais se dizia, no relatório, que a tendência na época era "a constituição de escolas de saúde pública do tipo das americanas e das inglesas." No continente europeu, o ensino da saúde pública era, "de uma maneira geral, bastante díspar” e, nalguns casos como na Suíça, nem sequer existia mesmo um ensino organizado.

Sobre a organização da Escola, o relator chamava a atenção para a importância da autonomia não apenas técnica e administrativa como pedagógica e científica: (...) "Uma das bases essenciais da orgânica de uma escola de saúde pública diz respeito à sua autonomia pedagógica, técnica e administrativa. É este um ponto em que estão de acordo autores nacionais e estrangeiros (...). O recente Relatório de Peritos para o Ensino da Saúde Pública, da Organização Mundial da Saúde, 1961, chama a atenção para a necessidade de conceder a máxima autoridade ao conselho de professores para a elaboração de programas e a criação de novos cursos" (...).

Nas conclusões, e no âmbito da apreciação na generalidade, o relator escreve: "A Câmara Corporativa é de parecer que não só se justifica, mas também é urgente a criação de uma escola nacional de saúde pública." Mais: essa escola deveria ter "um nível pós-graduado" e a sua sede em Lisboa. Enfim, deveria ser "criada na dependência do Ministério de Saúde e Assistência" e ter "amplas ligações" com: (i) a Universidade; (ii) o Instituto Superior de Higiene Dr. Ricardo Jorge; e (iii) o Instituto de Medicina Tropical (ponto 41, p. 152).

Em lado nenhum se defende, todavia, a criação de uma escola mista ou bicéfala, com dois ramos, o da saúde pública e o da medicina tropical, embora as duas áreas tivessem pontos comuns, como virá a acontecer com a solução, "ad hoc," "topdown," imposta por decreto, em 1966, a da criação da Escola Nacional de Saúde Pública e Medicina Tropical (abreviadamente, ENSPMT) (com entrada em vigor em 1/1/1967).

No exame na especialidade, o parecer da Câmara Corporativa vai ao ponto de apreciar com detalhe e fundamentar o elenco de disciplinas, reordená-las por importância e justificar algumas alterações de designação, relativamenteà proposta do Governo. As disciplinas sugeridas eram, por esta ordem de "importância":

(i) Técnica a Administração de Saúde Pública (considerada a "disciplina fundamental," e agregando a "Administração de Saúde Pública" e a "Administração Hospitalar"); (ii) Epidemiologia; (iii) Bioestatística; (iv) Saneamento (em vez de "Salubridade"); (v) Microbiologia e Parasitologia; (vi) Bioquímica e Nutrição (em vez de "Alimentação e Nutrição," designação considerada "redundante"; (vii) Fisiologia Aplicada e Medicina do Trabalho (em vez de Higiene e Medicina do Trabalho, de acordo com a nomenclatura da "escola de Londres"); (viii) Antropologia Social (em vez de "Sociologia"); (ix) Higiene Materno-infantil; (x) Higiene Mental (esta, nova, justificada pela emergência dos problemas de saúde mental, associados às "condições da vida moderna"); e, por fim, (xi) Educação Sanitária [dado o enfoque do ensino e da prática da saúde pública na "prevenção da doença e promoção da saúde” (sic), n 1, p. 136].

Como se vê, a proposta (a do ministro da Martins de Carvalho), tal como o parecer da Câmara Corporativa, era relativamente arrojada, numa época onde ainda era completamente estranho o conceito de "ciências sociais em saúde" (incluindo o direito, a economia, a antropologia e a sociologia da saúde).

No que respeita à sociologia, sabe-se que não era bem vista pelos responsáveis do regime, por razões teórico-ideológicas, algumas caricatas: Salazar, por exemplo, associava-a a um "socialismo disfarçado," ou no mínimo qualquer coisa de "inútil e abstrusa," no dizer de Sedas Nunes [41], que não se sabia muito bem o que era e para que servia... O que explicaria a subtil operação de cosmética do relator do parecer: "Dado que a saúde pública é um ramo da medicina que se ocupa das populações, ao contrário do aspeto individualista da medicina clínica, tornou-se indispensável o conhecimento dos problemas das populações, dos seus usos e costumes, do seu comportamento e estrutura, etc., para um melhor contacto dos profissionais da saúde pública com a massa com que têm de lidar. Daí ter-se tornado imprescindível, no trabalho de campo e na ação sanitária em geral, o concurso de especialistas no estudo da comunidade" (sic).

Sendo várias as designações que se atribuem a estes "especialistas" do estudo comunitário, o relator opta pela "Antropologia Social," dado a natureza e a abrangência do conteúdo do ensino que se pretendia ministrar: "A disciplina de Antropologia Social deverá estar intimamente ligada com o ensino da educação sanitária e prestará um valioso concurso a outras cadeiras da escola" (ponto $\mathrm{n}^{\circ}$ 45 , p. 155).

Sinal dos tempos, isto é, da história, em relação à $7^{\mathrm{a}}$ disciplina (Fisiologia Aplicada e Medicina do Trabalho), o parecer da Câmara Corporativa recomenda expressamente o seguinte: "Deve ser dado particular relevo, nesta disciplina, ao estudo da higiene e medicina do trabalho, dada a urgência em organizar, entre nós, com a necessária eficácia e amplitude, a proteção da saúde dos trabalhadores contra os riscos provenientes do trabalho e das condições em que este se efetua, para o que se toma indispensável dispor de um corpo de médicos devidamente prepa- 
rados." (ponto $\mathrm{n}^{\circ} 45$, p. 155). Como é sabido, logo em 1963 seria criado o curso de Medicina do Trabalho.

Entretanto, em 23/1/1963, dois anos passados (!) sobre a submissão do projeto de diploma, o presidente da Assembleia Nacional manda ler, antes da ordem do dia, um ofício do Presidente do Conselho, António de Oliveira Salazar, "em face do qual foi retirada a proposta de lei sobre a criação da Escola Nacional de Saúde Pública.” Assim, sem mais explicações, a não ser a de que o Governo ia reconsiderar o "problema"...

Sabe-se, em todo o caso, que o início da década de 1960 não foi fácil para o regime de Salazar, e muito menos para os portugueses. 1961 terá sido mesmo o "annus horribilis" de Salazar, pelas conhecidas vicissitudes internas e externas ocorridas, e que seria ocioso enumerar e desenvolver. A defesa do Ultramar "à outrance" torna-se uma das ideias obsessivas de Salazar, bem como a tentativa tardia (e falhada) de criar o mercado económico português (decreto-lei $n^{\circ} 44016$, de 24 de novembro de 1961) [42], para o qual seria naturalmente indispensável criar uma rede de serviços na área da saúde, da educação e da proteção social.

Era então ministro da pasta da Saúde e Assistência o prof. Pedro Mário Soares Martinez (de dezembro de 1962 a outubro de 1963) que, passados três meses depois da retirada do projeto de diploma de criação da ENSP, faz uma intervenção política de fundo, na $16^{a}$ assembleia mundial de saúde, em que afirma cinicamente que "the new National School of Public Health which is about to be set up in Portugal will certainly help to solve the problem of training health staff - a problem which everywhere is an extremely serious one" [43].

Apesar das repetidas declarações de lealdade aos princípios defendidos pela OMS, Portugal é pela primeira vez confrontado com a situação em Angola nesta $16^{\mathrm{a}}$ assembleia mundial de saúde, que se realizou em maio de 1963 e, como sempre, em Genebra, sede mundial da OMS.

À falta de mais informação de arquivo, não sabemos o que se terá passado, com a retirada do projeto de lei da criação da ENSP e a "intenção do Governo considerar de novo o problema da criação de uma Escola Nacional de Saúde Pública," nem muito menos as razões por que, já noutra legislatura (IX) (1965-1969), o governo acabou por optar por uma solução de recurso e que se irá revelar inconsistente e condenada ao fracasso: a união "de jure" entre a saúde pública e a medicina tropical, com uma dupla tutela, a da Saúde e Assistência e a do Ultramar que só a conjuntura política, interna e externa, poderia justificar... O "casamento" acabaria, lamentavelmente, em "divórcio"... institucional, seis anos depois, aparentemente sem honra nem glória para a saúde pública e a medicina tropical portuguesas.

Coriolano Ferreira, no livro de homenagem ao prof. Arnaldo Sampaio [44], faz uma referência este projeto de diploma de 1960, visando a criação da ENSP. Em vida ele poderia ter-nos elucidado sobre o "making of" do diploma, já que fez parte da respetiva comissão técnico-jurídi$\mathrm{ca}$ (e, inclusive, publicou o texto do projeto na sua revista "Hospitais Portugueses," no $\mathrm{n}^{\circ}$ duplo de novembro-dezembro de 1960: na íntegra, e sem qualquer comentário ou simples explicação, e omitindo o facto de ser "parte interessada") [45].

Um dos críticos mais frontais do projeto de criação da ENSP foi Arnaldo Sampaio que logo em 1963 levantava fortes objeções, e por razões porventura não totalmente nobres: um dos membros da comissão técnico-jurídica era um dos seus inimigos fidalgais, o prof. Cândido Oliveira, que em 1958 lhe travara o sonho de vir a ser professor da faculdade de medicina...

Em todo o caso, três anos antes, em 1960, Arnaldo Sampaio havia respondido a um inquérito da publicação periódica, "O Médico," justamente sobre "perspetivas e tendências em saúde pública," tal como antes dele Gonçalves Ferreira e a seguir a ele Luís Cayolla da Mota. Três das onze perguntas incidiam sobre o ensino médico e o ensino em saúde pública [46]. Confrontado com a pergunta "Parece-lhe necessária a criação de um Escola de Saúde Pública? Em que bases?," Arnaldo Sampaio começou por mandar uma pedrada no charco:

"Num país como o nosso, com um atraso flagrante na conceção de serviços de saúde pública, a criação de uma escola desta especialidade torna-se uma necessidade." Além disso, "no domínio dos princípios, não evoluímos depois da reforma de Ricardo Jorge."

Seguindo claramente o modelo da OMS, Arnaldo Sampaio apresenta e desenvolve as três bases fundamentais de uma escola de saúde pública: (i) ser um centro de investigação dos problemas de saúde pública; (ii) ter um corpo docente a tempo inteiro; e (iii) ter autonomia técnica e administrativa. "Na essência, é uma escola de administração especializada, no ramo da saúde pública," de nível pós-graduado, com a missão principal de preparar os "leaders" (sic, em inglês) dos serviços de saúde pública, e procurando recrutar os melhores alunos, aqueles que têm um potencial para a gestão ou para a investigação. E, implicitamente, faz uma crítica ao Instituto Superior de Higiene Dr. Ricardo Jorge (e ao seu curso de Medicina Sanitária) que até então, e em matéria de ensino, não passava de uma fábrica de diplomas, aqui fazendo-se eco de outros homens da saúde pública com responsabilidades 
no ensino (Fernando da Silva Correia, Carlos Arruda e outros).

Faz também uma forte crítica ao ensino superior no nosso país, incluindo o ensino médico. Inspetor superior da direção-geral de saúde, perito da OMS, professor do curso de medicina sanitário e "estrangeirado," Arnaldo Sampaio usa a sua autoridade profissional e científica para defender um novo conceito de saúde pública que incluiu a prevenção da doença e a promoção da saúde, o direito à saúde e a intervenção do Estado. Contra o falso argumento da pobreza do país e da alegada falta de dinheiro (usado pelo salazarismo), diz: "A falta de dinheiro é o bode expiatório das inépcias e da ausência de ideal.” E se é verdade que, "sem dinheiro não se podem executar programas de saúde," não menos verdade é que "sem ideais e sem técnica não se obtêm o dinheiro." Ora havia alguma ousadia neste discurso....

Por sua vez, Gonçalves Ferreira [47], em depoimento anterior, justificava igualmente a criação da ENSP, não só pelo nosso atraso nas "últimas décadas" mas também tendo em conta o princípio da conveniência de, "em países desenvolvidos a partir de cerca de 10 milhões de habitantes [, haver] um estabelecimento de ensino sanitário centralizado" (sic).

Uma das bases dessa escola, nacional, devia assentar na "dedicação exclusiva ao ensino e à investigação." Faz de igual modo uma crítica ao ensino médico da época em que os professores iam à faculdade, não para dar uma lição, mas para fazer um "discurso"... Além disso, "o atual ensino médico não tem em vista preparar técnicos com uma mentalidade de saúde pública," sendo "dominado pelo espírito da medicina clínica," ou seja, hospitalocêntrica e iatrocêntrica. E sobre a reforma do ensino médico, tema candente na época, acrescenta: "Conhecem-se bem não só as deficiências como a terapêutica mas é difícil aplicar os remédios."

Cayolla da Mota [48], nascido em 1923, representando uma nova geração de médicos de saúde pública, higienistas e epidemiologistas com formação no estrangeiro, também defendia a necessidade imperiosa de formação pré e pós-graduada em saúde pública, dos médicos, em geral, e dos futuros médicos sanitaristas, em particular, bem como do pessoal da saúde com funções de gestão e direção técnica. Para ele, a escola de saúde pública teria de ter "prestígio, autonomia técnica e administrativa, corpo docente categorizado e trabalhando em regime integral (...) e dispor de todas as facilidades indispensáveis à realização de investigações científica no campo da saúde pública."

Três anos depois, em 1963, na mesma publicação ("O Médico”), Arnaldo Sampaio [49] apresentava um resumo (alargado) da proposta que, em março de 1956, havia entregue ao subsecretário de estado da Saúde e Assistência, o dr. José [Guilherme Rato] de Melo e Castro (19141972), relativamente à criação da ENSP. A proposta tinha onze capítulos, sumariamente abordados e discutidos pelo autor: (i) introdução; (ii) necessidade de uma Escola de Saúde Pública; (iii) objetivos; (iv) orgânica; (v) corpo docente; (vi) contratos do pessoal docente e remunerações; (vii) direção da Escola; (viii) corpo discente; (ix) cursos regulares a ministrar; (x) disciplinas fundamentais; e (xi) horário.

Em 1956, Arnaldo Sampaio não tem dúvidas em defender a criação da ENSP como "secção de ensino" do Instituto Superior de Higiene Dr. Ricardo Jorge, estando nesse ponto de acordo com a comissão técnica de que fizera parte juntamente com Gonçalves Ferreira e outros. Seria uma escola, única, de nível pós-graduado, com um corpo docente e discente diversificado, ligado ao terreno, cabendo-lhe criar uma verdadeira cultura de saúde públi$\mathrm{ca}$, o que mais nenhuma outra escola de ensino superior (e muito menos as faculdades de medicina) estava em condições de ser capaz de fazer.

Esta proposta foi discutida no Conselho Superior e Higiene e Assistência Social, (criado em 1944). A Escola, dotada de autonomia técnica, administrativa, científica e pedagógica, seria dirigida por um diretor escolhido pelos seus pares (e não imposto pela tutela). Os docentes, responsáveis por departamentos e cadeiras, teriam que optar pelo tempo completo, podendo haver outros que seriam "convidados," oriundos ou não dos serviços. A ligação do ensino à investigação era fundamental.

Em agosto de 1961, Arnaldo Sampaio continuava a defender a necessidade, a conveniência e as vantagens de a futura Escola pertencer à saúde e não à educação: "A Universidade Portuguesa não tem tradição (...) [nem] as faculdades de medicina se têm mostrado interessadas neste ramo de ensino." Por outro lado, o jovem ministério da saúde só teria a lucrar com a criação e o desenvolvimento da ENSP.

Não obstante as "deficiências" que lhe podem ser imputadas e que decorrem em grande parte do curtíssimo prazo em que teve de ser elaborado e concluído, este relatório, segundo o seu autor, "tem interesse para que no futuro os historiadores da Saúde Pública Portuguesa" (sic) possam estar em condições de saber "interpretar os acontecimentos e compreender a medida oportuna do Governo, ao mandar retirar da Assembleia Nacional, há pouco, o projeto de organização da [ENSP], apesar deste projeto ter sido elaborado com a ajuda de peritos estrangeiros [, da OMS, ] e ter sido discutido durante mais de 
um ano no Conselho Superior de Higiene e Assistência Social."

Arnaldo Sampaio não tem pejo em opor-se frontalmente contra o projeto de Martins de Carvalho que, de resto, era um ministro com pouco peso político no governo de Salazar...

Quais eram as principais críticas de Sampaio a esse projeto de Martins de Carvalho? Segundo ele, o projeto do Governo "não se apresentava com as bases necessárias para justificar as despesas que a sua execução acarretaria"; por outro lado, "pretendia-se organizar uma escola modelo (de nível internacional, dizia-se), sem edifício, sem professores, sem serviços de saúde pública organizados de molde a poderem absorver os diplomados" (p. 354)... No fundo, seria mais um feudo, mais uma quintinha, mais um clã ("clan," em inglês) "como muitos que há na nossa terra, os quais, com o pretexto de servirem princípios superiores, defendem interesses e vaidades pessoais condenáveis" (sic)...

Que pessoas ou grupos poderiam estar por detrás deste projeto, para além do ministro da saúde e assistência, Martins de Carvalho, e dos "peritos da OMS"? Quem poderia ser visado na crítica de Arnaldo Sampaio? O próprio ministro, que nem sequer era médico, tendo a sua nomeação sido logo recebida com ceticismo, se não mesmo hostilidade, por parte da comunidade médica? E, para mais, as expetativas à volta da criação da nova tutela política da saúde foram cedo goradas quando os médicos, em geral, e a oposição democrática, por outro, se aperceberam de que Martins de Carvalho não tinha (nem era pressuposto ter) quaisquer meios para mudar o que quer que fosse.
Quem poderia mais, então, ser alvo das críticas de Arnaldo Sampaio? Possivelmente dois dos membros do grupo técnico-jurídico que elaborara a proposta de diploma, o Cândido Oliveira, professor da FMUL, e o Coriolano Ferreira, diretor-geral dos Hospitais, outro não médico, pioneiro na formação de administradores de saúde...

Não sabemos, nem tivemos ainda acesso às atas (se é que elas existem) do Conselho Nacional de Higiene e Assistência Social. Nem na época havia o saudável e democrático hábito de discordar publicamente, de maneira assertiva, sem escamotear, ignorar ou branquear o nome dos adversários...

Finalmente é criada a Escola Nacional de Saúde Pública e Medicina Tropical (abreviadamente, ENSPMT), em resultado da promulgação do decreto-lei 47102 [50], de 16/7/1966 (com entrada em vigor em 1 de janeiro de 1967). O diploma, que veio também extinguir o Instituto de Medicina Tropical (IMT), tem um seco preâmbulo com 4 pontos.

Na prática extinguia-se, por fim, quase 7 décadas depois, o velhinho Regulamento Geral dos Serviços de Saúde e Beneficência Pública, de 24 de dezembro de 1901, peça emblemática da já arcaica, obsoleta, mas sempre louvada reforma de Ricardo Jorge.

Foi Francisco Cambournac (1903-1994), conceituado especialista mundial em malária, e antigo diretor regional da OMS - África (1954-1964), quem presidiu à comissão instaladora da ENSPMT e foi o seu primeiro diretor (1967-1972).

\section{References}

1 Graça L. Ricardo Jorge e a modernização da saúde pública. In: Veloso AJ, Mora LD, Leitão $\mathrm{H}$, editors. Médicos e sociedade: para uma história da medicina em Portugal no século XX. Lisboa: By The Book; 2017. p. 34-49.

2 Amaral I. A medicina tropical (1902-1935). In: Veloso AJ, Mora LD, Leitão H, editors. Médicos e sociedade: para uma história da medicina em Portugal no século XX. Lisboa: By The Book; 2017. p. 50-65.

3 Dória JL. O XV Congresso Internacional de Medicina. In: Veloso AJ, Mora LD, Leitão H, editors. Médicos e sociedade: para uma história da medicina em Portugal no século XX. Lisboa: By The Book; 2017. p. 79-96.

4 XV Congrès International de Médecine, Lisbonne, 19-26 Avril 1906. Lisboa: Imp. Adolpho de Mendonça; 1906. 13 vols.
5 Silveira-Botelho L. A escola médica do Campo de Santana. Acta Med Port. 1995;8:259-64.

6 Decreto 1899. (1899-10-4). Aprova a reforma da organização superior dos serviços de saúde, higiene e beneficência públicas (Secretaria Geral do Ministério de Negócios do Reino).

7 Viegas V, Frada J, Pereira-Miguel J. Regulamento geral dos serviços de saúde e beneficência pública de 1901. In: Viegas V, Frada J, Pereira-Miguel J, editors. A Direcção-Geral da Saúde: notas históricas. Lisboa: Instituto Nacional de Saúde Dr. Ricardo Jorge; 2006. p. 9-14

8 Decreto-Lei no 35108. (1945-11-07). Reorganiza os serviços da assistência social.

9 Decreto-Lei no 413/71 (1971-09-27). Reorganiza os serviços do Ministério da Saúde e Assistência.
10 Despacho no 14/ME/94. Diário da República. 2a Série. 99 (29.04.1994) 3875

11 Silva-Correia F, editor. A vida, a obra, o estilo, as lições e o prestígio de Ricardo Jorge. Lisboa: Instituto Superior de Higiene Dr. Ricardo Jorge; 1960

12 Gonçalves-Ferreira FA. Como nasceu e se desenvolveu a ideia da criação do INSA; in $10^{\circ}$ aniversário do Instituto Nacional de Saúde Dr. Ricardo Jorge (INSA) (1971-1981). Arq Inst Nac Saúde 1981;6:98.

13 Portugal. Ministério do Reino. Inspeção Geral dos Serviços Sanitários do Reino. Boletim dos Serviços Sanitários do Reino. 1903, Edital de 9 de janeiro de 1903.

14 Silva-Correia F. A lição da História: evolução geral do Instituto de Higiene. Boletim do Instituto Superior de Higiene Doutor Ricardo Jorge. 1946;I(1):44-45. 
15 Burguete MC, Martins DR, Fiolhais C. Evolução dos estudos médicos em Coimbra no século XIX: contribuição das ciências físico-químicas. In: Fiolhais C, Simões C, Martins DR, editors. História da ciência na Universidade de Coimbra (1772-1933). Coimbra: Imprensa da Universidade; 2013. p. 167-92.

16 Santos JC. Azevedo Neves, pioneiro da Medicina Legal. In: Veloso AJ, Mora LD, Leitão $\mathrm{H}$, editors. Médicos e sociedade: para uma história da medicina em Portugal no século XX. Lisboa: By The Book; 2017. p. 127-41.

17 Portugal. Ministério do Reino. Inspeção Geral dos Serviços Sanitários do Reino. Boletim dos Serviços Sanitários do Reino. Edital de 21 de fevereiro de 1903. Edital de 7 de março de 1904.

18 Portugal. Ministério do Reino. Inspeção Geral dos ServiçosSanitários do Reino. Boletim dos Serviços Sanitários do Reino. Edital de 7 de março de 1904.

19 Ávila HG. Alguns apontamentos para a história do Instituto Central de Higiene. Boletim do Instituto Superior de Higiene Doutor Ricardo Jorge. 1946;I(1):48-80.

20 Decreto de 14 de fevereiro de 1903 (1903-0214). Aprova o regulamento de salubridade das edificações urbanas.

21 Decreto com força de lei de 26 de maio (191105-26). Cria os Serviços de Sanidade Escolar.

22 Decreto com força de lei de 22 de fevereiro. Diário do Govêrno no $45 / 1911$. Série I. (191102-24). Reforma o ensino médico.

23 Decreto com força de lei de 6 de abril. Diário do Govêrno no 81/1911. Série I. (1911-04-08). Determina que o Instituto de Ophtalmologia de Lisboa e o Instituto Central de Hygiene sejam pedagogicamente anexados à Faculdade de Medicina de Lisboa.

24 Dias AA. Catálogo provisório da biblioteca do Instituto Central de Higiene. Arquivos do Instituto Central de Higiene. 1915; I Suplemento:IV-LXXXVI.

25 Furtado CA. curso de medicina sanitária [: discurso de abertura]. Boletim do Arquivo do Instituto Superior de Higiene. 1945. Ano;I(1): 291-3.

26 Decreto $\mathrm{n}^{\circ}$ 36050. Diário do Governo n. ${ }^{\circ}$ 288/1946. Série I. (1946-12-18) -12-18 148591. Regula a admissão aos cursos de medicina sanitária.

27 Instituto Superior de Higiene Dr. Ricardo Jorge. Programas do Curso de Medicina Sa nitária. Boletim do Arquivo do Instituto Superior de Higiene. 1945;I(1):294-304.
28 Silva-Correia F. O Instituto Superior de Higiene Dr. Ricardo Jorge em 1951: relatório. Boletim do Instituto Superior de Higiene Doutor Ricardo Jorge. 1952;VII:59.

29 Silva-Correia F. O cinquentenário do Instituto de Higiene. Boletim do Instituto Superior de Higiene Doutor Ricardo Jorge. 1952; VII: $161-81$.

30 Portugal. Assembleia Nacional. Diário das Sessões, III legislatura, Sessão no 45 de 24 de fevereiro de 1944. Lisboa: Assembleia Nacional; 1944.

31 Faria JA. Preceitos sanitários. Lisboa: Imprensa Nacional; 1936.

32 Portugal. Assembleia Nacional. Ponto 64. in Diário das Sessões, III legislatura, Sessão no 45 de 24 de fevereiro de 1944. Lisboa: Assembleia Nacional; 1944, p. 123.

33 Ferreira OM. História da Escola Técnica de Enfermeiras (1940-1968): aprender para ensinar e profissionalizar. Lisboa: Universidade de Lisboa, Instituto de Educação, 2013. Tese de doutoramento em educação (Especialidade: História da educação).

34 Silva-Correia F. Origens, evolução e conceito do serviço social. Separata do "Diagnóstico Social". Lisboa: Instituto de Assistência à Familia; 1950.

35 Meliço-Silvestre A. Ecos da Conferência de Nancy. Boletim do Instituto Superior de Higiene Doutor Ricardo Jorge. 1952;VII:276303.

36 Portugal. Assembleia da República. Actas da Câmara Corporativa, VII Legislatura, no 121 de 26 de janeiro de 1961. Lisboa: Assembleia da República; 1961. p. 1221-5.

37 Gonçalves-Ferreira FA. (Nota biográfica e apresentação: António Correia de Campos). Sistemas de saúde e seu funcionamento: história da saúde e dos serviços de saúde em Portugal. Volume III. Lisboa: Fundação Calouste Gulbenkian; 2015.

38 World Health Organization. Official Records of the World Health Organization: thirteenth World Health Assembly, Geneva, 3-20 May 1960: Part II: Plenary meetings: verbatim records; Committees: minutes and reports. Geneva: World Health Organization; 1960.

39 Portugal. Assembleia da República. Actas da Câmara Corporativa, VIII Legislatura, $n^{\circ} 27$ de 26 de novembro de 1962. Parecer n 5/VIII: projeto de proposta de lei no 519/VII: Escola Nacional de Saúde Pública. Lisboa: Assembleia da República; 1962. p. 135-61.
40 WHO Expert Committee on Professional and Technical Education of Medical and Auxiliary Personnel. Recommended requirements for schools of public health: tenth report of the Expert Committee on Professional and Technical Education of Medical and Auxiliary Personnel. WHO Technical Report Series 216. Geneva: World Health Organization; 1961.

41 Sedas-Nunes A: Histórias, uma história e a História: sobre as origens das modernas ciências sociais em Portugal. Análise Social. 1998;XXIV (100-1):11-55.

42 Decreto-lei no 44016.(1961-11-08) Diário do Governo. $\mathrm{n}^{\circ}$ 259. Série I. Promulga disposições destinadas a promover a integração económica nacional.

43 World Health Organization. Official Records of the World Health Organization: sixteenth Word Health Assembley, Geneva, 7-23 may 1960, Part II: Plenary meetings: verbatim records; Committees: minutes and reports. Geneva: World Health Organization; 1963. p. 142

44 Ferreira C. O Prof Arnaldo Sampaio e a Escola Nacional de Saúde Pública: alguns momentos de história. Livro de Homenagem ao Professor Arnaldo Sampaio. Lisboa: Escola Nacional de Saúde Pública; 1980. p. 15-7.

45 Escola Nacional de Saúde Pública. Projeto da Escola Nacional de Saúde Pública. Hospitais Portugueses. 1960;101-102:57-61.

46 Sampaio A. Perspetivas e tendências em saúde pública: depoimento. O Médico. 1960;XVI (470):277-284.

47 Gonçalves-Ferreira F. Perspetivas e tendências em saúde pública: depoimento. O Médico. 1960;XVI (468):218-224

48 Mota L. Cayolla da: Perspetivas e tendências em saúde pública: depoimento. O Médico. 1960;XVII (494):474-487.

49 Sampaio A. Considerações à margem do ensino da saúde pública em Portugal. O Médico. 1963;14:354-64.

50 Decreto-lei 47102. Diário do Governo n ${ }^{\circ}$ 164/1966. Série I (1966-07-16). Cria a Escola Nacional de Saúde Pública e Medicina Tropi$\mathrm{cal}$.

51 Silva-Correia F: O cinquentenário do Instituto Superior de Higiene Dr. Ricardo Jorge em 1951: relatório. Boletim do Instituto Superior de Higiene Doutor Ricardo Jorge. 1952;VII:55-80.
Origens e história do ensino da saúde pública em Portugal
Port J Public Health 2018;36:115-133 